\title{
PALEOGEOGRAPHY OF SAINT PETER TIME
}

\author{
BY CHARLES P. BERKEY
}

(Presented by title before the Society December 29, 1905)

\section{CONTENTS}

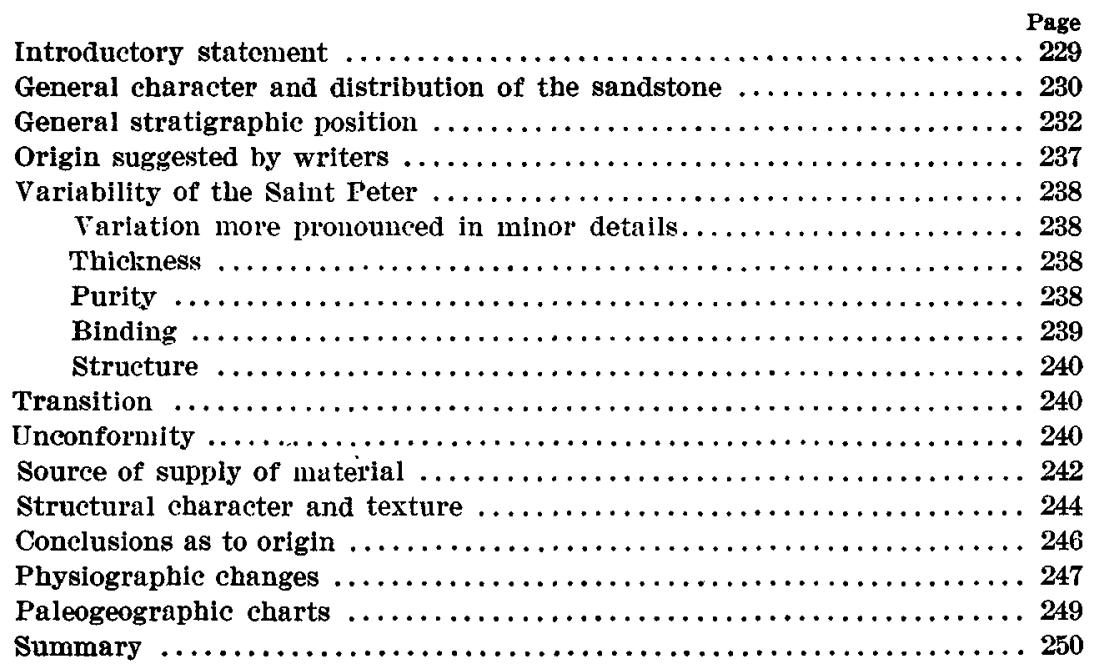

\section{INTROdUctory Statement}

The Saint Peter sandstone is one of the most prominent Ordovicic formations of the Mississippi valley. Because of its striking characters it has attracted comment from almost every geologist whose work lay within this territory. Most of them have been led to suggest an explanation of its remarkable purity, or its apparent uniformity, or its structural relations. Many have regarded the formation one of the most puzzling of the region, the obscure problem being that of origin.

The following study is primarily one of the physiographic conditions represented in Saint Peter time. It has led to a comparative study of this formation as described from many localities and by many observers. 
This data has been checked wherever possible by the writer's own observations,* which, together with his examinations $\nmid$ of material, form the basis of the discussion.

The work has been carried on in the Stratigraphic Laboratory at Columbia University, and was undertaken at the suggestion of Professor Grabau, in whose classes the researches have been discussed and to whom the writer is indebted for many suggestions.

The Saint Peter sandstone has often been described in admirable detail. + 'To this feature the present writer has added little. To the comparative side and the resulting interpretation as to conditions prevailing during the time represented by this formation this discussion of what is otherwise so well worn a subject is directed. If the conclusions are well founded, then ther explain the problem of origin also; and its uniformity of grain, its purity of composition, its great extent, its apparent conformity to adjacent beds are not inexplicable sedimentary puzzles.

From the nature of the undertaking, it will be necessary to summarize the essential points of the facts gathered from observers touching this formation and later to compare and interpret local variations.

Since finishing the manuscript of this article $\S$ the writer's attention has been called to a paper by A. Rutot, which contains a very suggestive discussion of the principles involved in sedimentation, and includes the same ideas and general treatment that are here applied to a particular case.

\section{General Character and Distribution of the Sandstone}

The Saint Peter formation is a quartz sandstone, a silicarenyte. In most descriptions the same characteristic are enumerated. It is coarse and uniform grained, with almost no cementing material and little im-

\footnotetext{
* These consist of tield observations for many years in the Upper Mississippi Valley region.

$\dagger$ Recent laboratory study of material obtained from localities distributed throughout the areal extent of the formation.

To attempt a complete acknowledgment of the sources of information on this subject is scarcely practicable. They are exceedingly numerous. The chlef publications relled on, however, are those of the Geological and Natural History Survey of Wisconsin, the Geological and Natural History Survey of Minnesota. the Geological Survey of Iowa, the Geological Survey of Missouri, the Geological Survey of Illinols, the Geological Survey of Michigan, including descriptions and discussions by $T$. C. Chamberlin, N. H. Winchell, W. H. Norton, C. R. Keyes, Sanuel Calvin, James Hall, J. D. Whitney, A. H. Worthen, James Shaw, F. L. Nason, and others. Among authors of important special papers or reports are D. D. Owen, Joseph F. James, C. W. Hall, F. W. Sardeson. Citations are made to many of these at appropriate points throughout the paper and especially in those matters with which the present discussion is mainily concerned.

8. A. Rutot: Les Phénoménes de la Sedimentation Marine. Bull. Musée Ropal d'Histolre Naturelle de Belgique, T. 11, 41-83, 1883.

Hournal of the Cincinnati Society of Natural History, July, 1894, p. 120. The St Peter's Sandstone, by Joseph F. James.
} 
purity. At most typical localities the composition is about 99 per cent $\mathrm{SiO}_{2}$. In color there is considerable variation, locally, chiefly due to iron stains, but at the typical exposures it is white or yellowish, often only faintly streaked with color.

Usually the rock is massive, with only occasional bedding planes or color zones or other structural featmres.

This formation, considering its exceptional character, has very wide distribution. Its outcrops occur along a zone including sontheastern

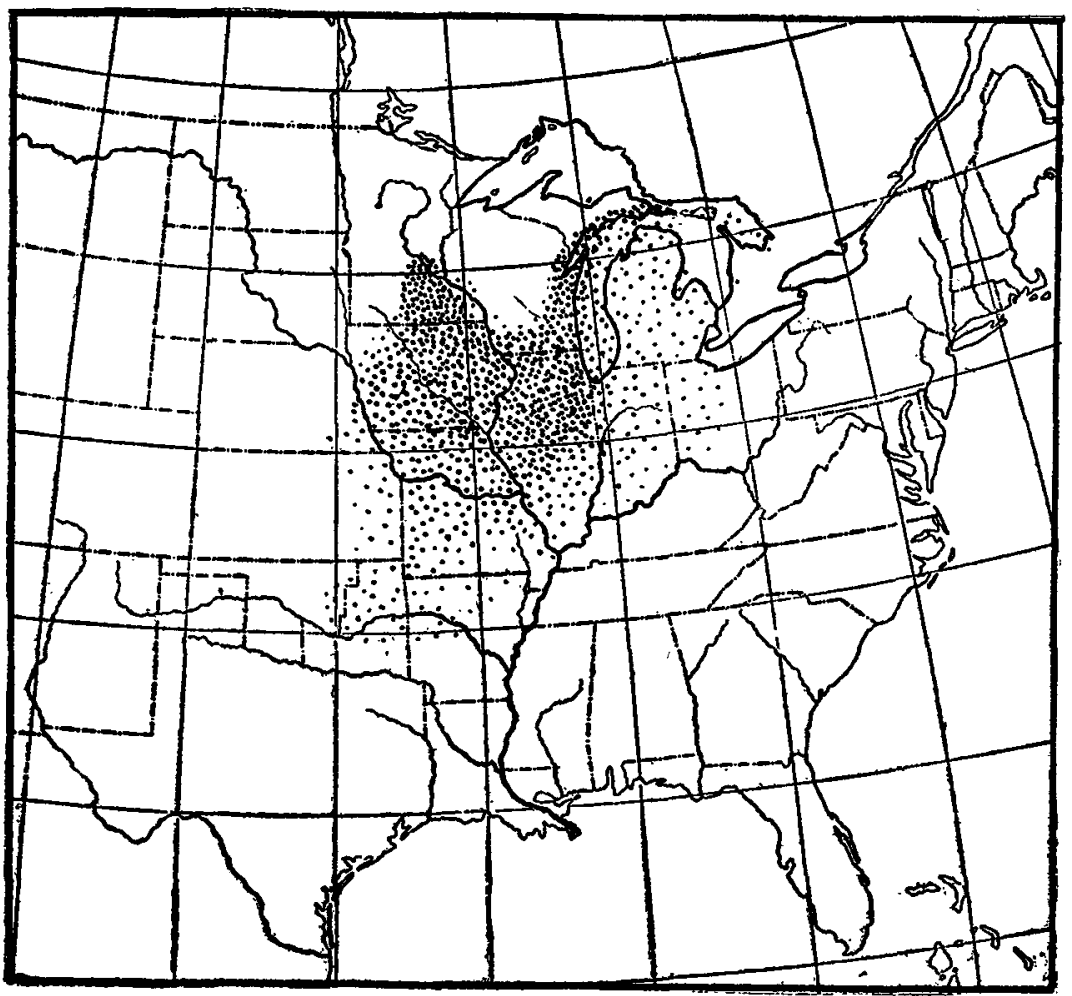

FIGUR 1.-Areal Distribution of the Saint Peter Sandstone Formation

Minnesota to the vicinity of Minneapolis and Saint Paul, soutlıwestern and southern Wisconsin and a narrow fringe along the eastern margin of that state; a like strip across the northern peninsula of Michigan, passing into southern Canada in the vicinity of Saint Joseph island, continuing in an easterly course. It has a most typical development in northern Illinois and portions of eastern. Iowa. There are also outcrops of the same formation in Missouri. 
From the distribution of the outcrops, together with the records of deep wells and local stratigraphic interpretation, it is certain that the Sain Peter area includes almost the whole of Iowa, Illinois, and Missouri, together with large areas in Minnesota, Wisconsin, Michigan, and Indiana, as well as less clearly defined portions of Nebraska, Kansas, Arkansas, Indian Territory, and possibly North Dakota. The northerly border of this great tract exhibits the upturned eroded edge of the Saint Peter in characteristic facies. The southerly and easterly border, on the other hand, passes more and more deeply beneath later sediments, beyond observation except by deep well records. These indicate, however, a gradual increase of argillaceous and calcareous matter in this direction. The distribution and boundaries are plotted on the accompanying outline map.

\section{General stratigraphio Position}

The Saint Peter is Ordovicic in age. In its northerly exposures it is overlain by a limestone that is correlated with the Stones River formation by Ulrich and Winchell,* and it is underlain by a dolomite, called the Shakopee, also Ordovicic in age, but of doubtful equivalence. The descending series of dolomites, shales, and sandstones beginning with the Shakopee, known as the "Magnesiun series," $\nmid$ carries somewhere the line dividing Cambric from Ordovicic time, but the exact position of it is uncertain. The base of the Paleozoic column is represented by a thick sandstone and conglomerate, commonly referred to as the Potsdam or the Basal sandstone, or the Saint Croix formation, by workers in different fields.

The Saint Peter therefore occupies a position well toward the base of the Ordovicic series, and it is the uppermost one of the five sandstone formations which give a predominant arenaceous character to the basal Paleozoic rocks of the northern Mississippi Valley region. This relationship is indicated in figure 2.

In other areas, especially southward, there may be conditions of overlap that modify minor stratigraphic relationships of succession, as will be indicated in another paragraph.

It has been common usage to correlate the Saint Peter with the Calciferous (Beekmantown) or with the Chazy of New York. This has been done more on the order of succession and similarity of rock type than any direct evidence. The fow fossil forms found give little help in exact correlation.

* Geol. and Nat. Hist. Survey of Mfinnesota, Final Report, vol. iil, part 11, pp. xclii-xclv. $\dagger$ Bull. Geol. Soc. Am., vol. 6, pp. 167-198. 
Lithologic similarity in widely separated areas is a most questionable basis for correlation or time equivalence.

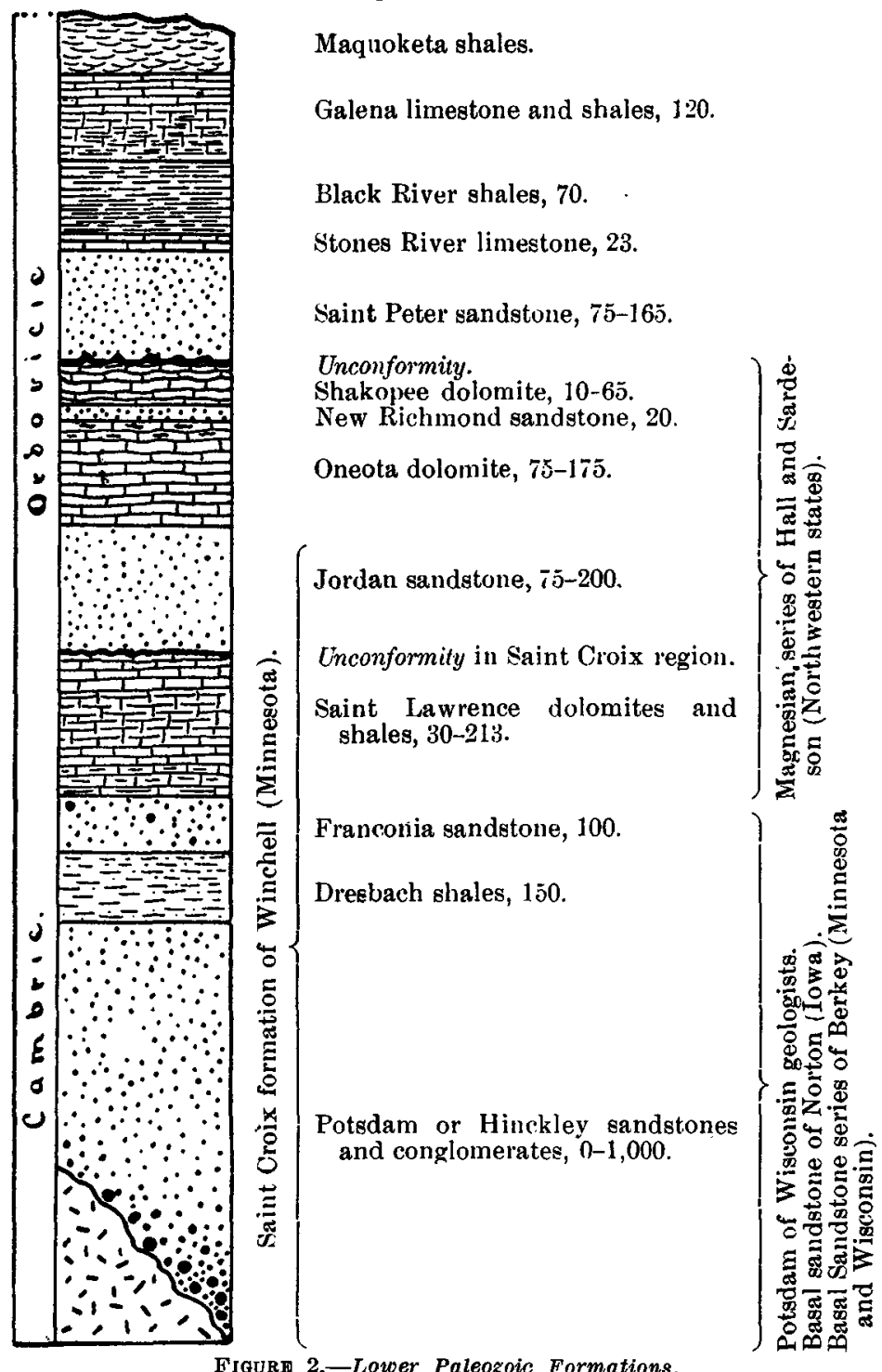

Upper Mississippl Valley region. Relative thickness of members of the series is that of southern Minnesota.

Besides, in this case, even if the beds could be followed continuously from west to east, a former laxil harricr seems to have actually separated 
the two seas in which the typical formations were accumulating. This still further increases the difficulty of direct comparison and makes any statement of exact correlation in terms of Chazy or Calciferous (Beekmantown) of doubtful value. The only method left is by the indirect process of comparing the succession from a well established base of uniformly recognized formation.

'The formation best suited to this datum-plane use is the Black River beds. They have a more universal extent than any other of the lower members of the series, in that they cross the New York divide (Frontenac axis) and are recognizable in both ancient seas.

On the east side of the divide, in the ancient sea that occupied New England and the eastern borders of New York, was laid down a continuous series whose succession is as follows:

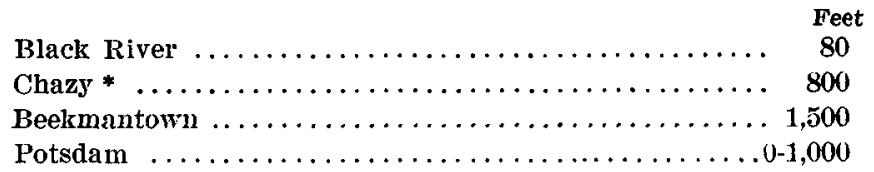

On the west side of the divide the Chazy and Beekmantown are not at all or only partially developed. Their time equivalents are represented in the formations and erosion intervals preceding the Black River beds, as they overlap against the flank of the Adirondacks. The first one of these below the Black River is the Lowville, resting on the basal conglomerate and Archean gneiss of the protaxis on the west side of the Adirondacks. In the Mohawk valley some 400 or 500 feet of Beekmantown rest on the pre-Cambric gneiss, followed after a pronounced erosion interral by a few feet of the upper Lowville, which grade into the Black River. As shown by well borings, successive members of the very extensive series of lower Ordovicic and Cambric sediments appear one below another at greater and greater distance from the crystallines. Toward the southwest there are prevailingly limestones and dolomites constituting the Stones River group and Knox dolomite, which together attain a great thickness.

In the interior sca, the so-called Mississippian sea, there is a close relationship of formations. There is, howerer, much variety in the series along the margins, and the numerous breaks and oscillations make it possible locally to subdivide minutely with success. In the deeper, less clisturbed, sea basin there was apparently continuous sedimentation and a fairly uniform type of deposit resulted. Into this each marginal type

* Brainard and Seeley : Bull. Am. Mus. Nat. Hist., vol. vili, p. 305.

American Geologist, vol. 1f, p. 323.

Brainard : Bull. Geol. Soc. Am., vol 2, p. 293. 
shades by gradual merging of character and each break or interval terminates in wedge-like form.

In this Paleozoic interior basin the Mississippian sea of Cambric time advanced slowly from the southward and in its marginal encroachment spread out the great basal conglomerate and sandstone series that is so prominent in the Upper Mississippi valley and the Great Lake region, where it is of Upper Cambric to Lower Ordovicic age. With successive oscillations of level, and accompanying variation in character and supply of sediment, the whole series accumulated. They are largely sandstones near the base and prevailingly limestones at higher levels and at greater distances from shore; but almost without exception the margin was everywhere gravel and sand-a continually advancing sheet of conglomerate and sandstone, growing younger step by step with the northward advance, a continuous lithologic formation, but, in its successive stages, of very unlike time equivalence. It probably ranged from lowest Cambric

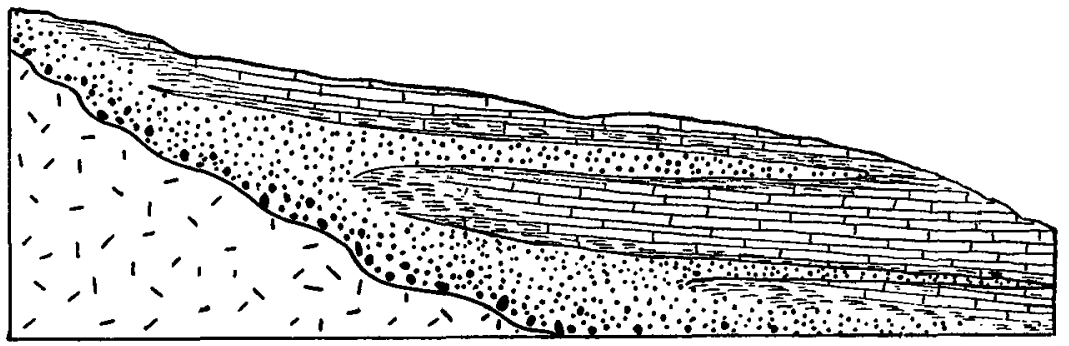

FIGURE 3.-Generalized sketch illustrating Relationship of interbedded sandstones to great Basal sandstone Formation.

in the southern United States continuously to and including the Saint Peter of the Ordovicic on its original margins.

With each recurring period of elevation of the land, or retreat of the sea, or excessive waste supply, the sands crept seaward over the deeper sea types of deposit; and with each subsidence and consequent adrance of the sea the sand was left behind as a continuous bed, to be covered in large part by other sediments. Naturally enough the nearer to the margin of the sea a locality is the greater prevalence of sand is to be noted in its series of formations, and, other things being equal, the greater the number and the greater the thickness of the interbedded wedge-like sandstone formations.

The Saint Peter is the fifth and last one of these sandstone formations in the Upper Mississippi valley.

Of great significance is the comparative thickness of the involved formations in different parts of the region. In this discussion the formations both above and below the Saint Peter must be included. 
Ulrich and Winchell* correlate the 300 to 400 feet of Stones River limestones and shales of Kentucky and Tennessee with the 23 feet of limestone just above the Saint Peter in Minnesota, remarking that the Minnesota organic forms are most like those of the uppermost member of the Stones River of Kentucky.

Part of the Knox dolomite of Tennessee below the Stones River group is also credited to the Ordovicic; how much should be is not known; but this much is clear, that in the Kentucky-Tennessee area there was continuous marine deposition, chiefly of a limestone character, amounting to probably 1,000 or 1,500 feet, during the time from the close of the Cambric to the end of Stones River time-a period marked in the northwest by the deposition of 75 to 150 feet of shaly limestones and dolomites and 150 feet of sandstone, within which there is at least one break of some significance.

Only the upper representatives of the Stones River group also are to be seen in western New York, where the Lowville overlaps against the earlier formations, as noted by Ulrich.

Broadheadt calls attention to the interpolation of 80 to 190 feet of the Missouri survey's "First Magnesian" between the Saint Peter and the "Trenton limestone." This formation does not appear at all in the northernmost areas, and, while the underlying magjes an formation has a thickness in Missouri of 150 to 230 feet, in Minnesoca or Wisconsin it seldom reaches 75 feet. It appears therefore that the formations thicken considerably southward.

The Shakopee below the Saint Peter is correlated with the Calciferous (Beekmantown) of New York by Sardeson. $\ddagger$

The same author has described the fossils $\$$ found in the Saint Peter

* Geol. and Nat. Hist. Survey of Minnesota, Final Report, vol. 1il, part 1i, introduction.

† American Geologist, vol. 34, no. 2, August, 1904.

Bull. Minn. Acad. Nat. Sci., vol. iv, no 1, p. 104.

There are marine fossils in the upper part of the Sair nesota. These have been described by Sardeson in Bull. Min no. 3, and vol. 1v, no. 1, p. 79. The following genera are $1 x_{1}$ ted: Cypricardites, 4 species; Modiolopsis, 5 specles; Tellinomya, 2 species; Holopea, . scles; Murchisonia, 2 species; Ophileta, Platyceras, and Pleurotomaria, 1 species each; 0 , ihoceras, 3 species, and one species each of Crania, Lingula, Orthis, Ptylodictya, and Rauffella.

There were found at this place 28 spectes. Although nearly all described as new species, they are as a whole very like the forms occurring in the overlying limestone. Other localitles have furnished a few forms. At Ripon, Wisconsin, in transition beds, Orthoceras is found. Except fucoldal markings and Scolithus Minnesotensis James, there are no others reported from Wiscousin.

Winchell reports Scolithus from Faribault, Minnesota, probably the same as $\mathcal{S}$. Minnesotensis James. (The Saint Peter Sandstone, Cin. Soc. Nat. Hist. Jour., 1894, p. 134.) At Fountain, Minnesota, in transition beds to Stones River above, not in typical Saint Peter, Lingulepsis morsensis Winchell and an Orthis resembling o. testudinaria. Planolites is also reported from Minuesota.

Meek refers to a Murchisonia and a crinold column from Monteau county, Missouri; Shumard reports a Straporollus and a Chemnitzia from Ozark county, Missouri, and an Orthoceras is recorded from Maries county, Missouri. 
TENNESSEE.

MINNESOTA.

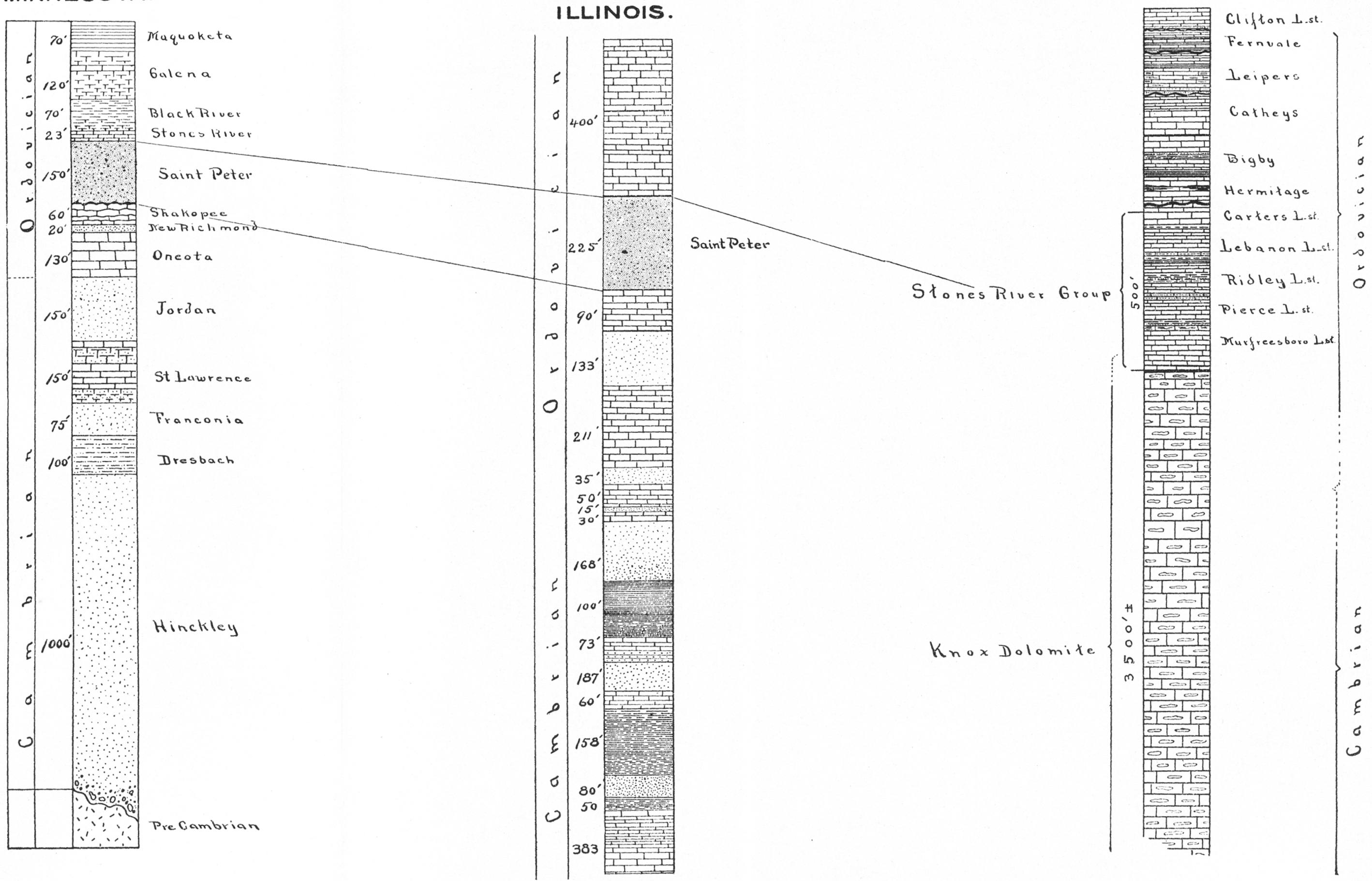

CAMBRIC AND ORDOVICIC SERIES IN SOUTHERN MINNESOTA, ILIINCIIS, AND TENNESSEE

Representing the series of sandstones characteristic of the Northern region, the comparatively uniform succession of dolomites in the south, and the intermediate equivalents. The Illinois section is from well records. 
near Saint Paul, Minnesota, and concludes from them that this formation is much more nearly allied to the overlying Stones River than to Shakopee below. This is in accord with the existence of a break between the Shakopee and the Saint Peter, indicated both by the unconformity between them and the cessation of sedimentation that has resulted in thinner beds on this margin.

Therefore the uppermost Saint Peter, especially in its northern margin, is Stones River in age; but the whole formation is involved in a retreat and advance of the sea over the area, and has, as is usual in sandstones, no perfect time unity in its whole extent; and the break, except where it has imprinted erosion features on the underlying Shakopee, is swallowed up in the sands of the deposit.

A few columns drawn to scale (see plate 24 ), with the lines of the formations indicated, will serve to better show the relationship.

\section{ORIGIN SUGGESTED BY WRITFRS}

There have been many different theories as to the origin of the Saint Peter sands and their present purity. Its extreme purity and great extent seem to have made ordinary sedimentation processes appear insufficient to many observers. In accord with this idea, several early writers have suggested* chemical precipitation as a probable origin. Most observers, however, have agreed to the mechanical character of the deposit and have suggested a variety of subordinate agencies.

James Shaw, in the geological reports of Illinois, at one time advocated the wind as the effective agent in producing the cross-lamination and ripple-like marks, but later seems to have abandoned this idea. Norton of Iowa also suggests the wind as a probable factor. Owen and many others seem never to have considered any modification of the ordinary sedimentary origin necessary. Sardeson, $\nmid$ on the other hand, while maintaining the sedimentary origin, considers the unusual purity due chiefly to the porosity of the rock, favoring free circulation of underground water and the consequent leaching out in solution of all constituents except the quartz grains.

Any more definite statement than that the Saint Peter owes its existence and character to the usual processes of sedimentation depends for support more on the variability of character than upon its reputed con-

* Keating, Hall and Whitney, Winchell.

† Sardeson: Bull. Minn. Acad. Nat. Scl., vol. Iv, no. 1, 1896, p. 86. 
stancy. The views of the writer as to origin are necessarily involved in a discussion of these lines of evidence.

\section{Variability of The Salst PETER \\ VARIATION MORE PROMIIENT IN MIIOR DETAILS}

A minute study makes it clear that the reported constancy of this formation is somewhat overdrawn. In the broader characteristics of sandstone formations, it is fairly constant, but in minor detail it is very variable, and these usually neglected variations, it is thought, are in this case a key to the bit of history that the Saint Peter represents.

\section{THICKNESS}

This formation varies in thickness from a mere film, a laver of sand grains, as in certain cases in eastern Wisconsin, to 225 feet in Illinois.* It occasionally exhibits a range of from 1 foot to 100 feet within so short a distance as a quarter of a mile. $\dagger$

This rapid change is described as due to the undulating magnesian limestone floor. The normal thickness in Iowa is about 100 feet, and this may be taken as a fair estimate of its average thickness over the greater part of the whole region of its distribution.

\section{PURITY}

Although more than 99 per cent pure quartz in some localities, this condition is by no means universal. An analysis given by Hall and Sardeson shows for the fossiliferous rock occurring at South Saint Paul: $\ddagger$

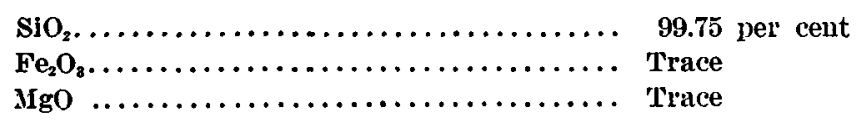

A Minneapolis sample gave 98.50 per cent of $\mathrm{SiO}_{2}$.

The saccharoidal sandstone (Saint Peter) of eastern Missouri, in the vicinity of Saint Louis, so important for many years past in the glass industry, is also remarkably pure. It is given as more than 99 per cent $\mathrm{SiO}_{2}$.

The Saint Peter, however, is not always free from clastic impurity. Hall and Sardeson note the presence of fine white kaolin in the Saint Anthony area.

* Geological Survey of Illinois, vol. vil, p. 49.

$\dagger$ T. C. Chamberlin : Geology of Wisconsin, vol. ii, 1887, pp. 285-286.

$\ddagger$ Bull. Geol. Soc. Am., vol. 3, p. 351. 
There are shale intermixtures at Boone, Iowa, calcareous and shale intermixtures in Wisconsin, and iron oxide hearily developed in a few places. The formation in Missouri, Indiana, Ohio, and Kentucky carries a marked percentage of lime and argillaceous matter in contrast with the average northern outcrops.

Specimens at hand from Ia Salle county, Illinois, show a considerable percentage of earthy impurity, while one from Wisconsin, probably a transition phase, is very heavily charged with carbonates, though on the whole the Saint Peter is a remarkably pure sandstone formation. Its greatest variability is marginal and throws some light on the question of origin and conditions prevailing during its accumulation. This variability, however, is markedly different along opposite margins-that is, the landward as opposed to the seaward side-and is well within the range of characters in every respect that one should expect. Thus on the northern margin there are developed occasionally breccias and marginal conglomerates and various foreign intermixtures, while far southwart the Saint Peter and its equivalents become shaly sandstones, calcareous shales, and even siliceous limestones.*

\section{BINDING}

Throughout most of its extent the individual grains of the Saint Peter have almost no binding. At Minneapolis a freshly exposed fragment may be crushed in the hand or its grains readily rubbed off by the fingers. In all cases exposure increases the strength of the bond, so that occasionally it has been made use of in light structures. In Ogle county, Illinois, $\nmid$ it is recorded that the outcrops, although apparently of so friable material, resist weathering with great success.

Occasionally in other localities there is strong lime or iron oxide binding, while local induration to a quartzite is less common. A sample from Missouri sent by the kindness of Dr E. M. Buckley exhibits secondary growth of almost every grain, the pyramidal faces being especially sharply developed and occasionally developing almost a complete doubly terminated quartz crystal; yet the rock is not well cemented; it is not much more firm and resistant than the average specimen.

In all cases there is either a striking lack of cementation or if well developed it is extremely local. The places where iron oxide is infil-

* Marginal character may have prevalled also in Pennsylvania and West Virginla, as well as along some continental border in the west, but if so the type of rock is different and is not recognized as Saint Peter.

$\dagger$ James Shaw : Geology of Illinois, vol, v, p. 116. 
trated furnish some firmly bound rock, but this is in irregular bands rather than a general constituent.

\section{STRUCTURE}

In many places the rock is massive, with but faint traces of bedding or any other marking. At still others the bedding planes are strongly marked and the beds comparatively thin, passing in numerous places into shaly facies. Often there is cross-bedding, as noted particularly in northern Illinois, with ripple marks well developed. These irregularities are still further accentuated by color streaking. Variations are much more notable in the central portion of the Saint Peter area than on its margins, although they are not wholly lacking along the northern margin. Chamberlin* refers to structures typical of ebb and flow and ripple marks in Wisconsin.

Nearly all the strong coloring described in the Saint Peter is confined to structural inequalities, mostly bedding or cross-bedding lines. In so porous a rock of so simple composition one would not expect enough selective capacity to connect the color streakings with late infiltration. Even the coloring seems to point back to the conditions under which t!.e rock accumulated.

\section{Transition}

There are occasionally brecciated and conglomeritic Lower Magnesian fragments in the marginal facies of the rock in eastern Wisconsin andi northern Michigan. Uusually the transition from Magnesian dolomite to Saint Peter and from Saint Peter to Stones River limestone again is abrupt, but even this is not universal, sand mixed with calcareous matt: $r$ or clay mixed with the sand being an occasional variation.

The overlying limestones and shales of the Stones River group at aii places are described as perfectly comformable to the Saint Peter.

\section{UNCONFORMITY}

The underlying dolomite and the succeeding Saint Peter are frequently unconformable. This condition has been described in Michigan, Wisconsin, Iowa, and Missouri, where occasionally the dolomite floor is very uneven. In places the dolomite floor is so hummocky as to project up through the whole thickness of the Saint Peter, so that the sandstone only fills the hollows and valleys.

In generalizing the isolated descriptions it appears that the greater

\footnotetext{
* Geology of Wisconsin, vol. i, p. 146.
} 
conformity as a rule obtains at the greater distance from the continental land margin of ancient Laurentia. In Missouri, according to Winslow, there is an unconformity below the saccharoidal sandstone, now correlated with Saint Peter, and erosion valleys have been described there.*

Throughout the greater part of the region of the Saint Peter the lower contact is not within surface observation, so that, even if unconformity were general, most descriptions would necessarily fail to note it.

In a few isolated areas where the original landward margins are still preserved, or where ancient islands project through, the Saint Peter seems to merge into the Basal sandstone, Potsdam, either by thinning out of the Magnesian series or by its destruction and overlap, so that the break is swallowed up in the uniform textured sandstone formation.

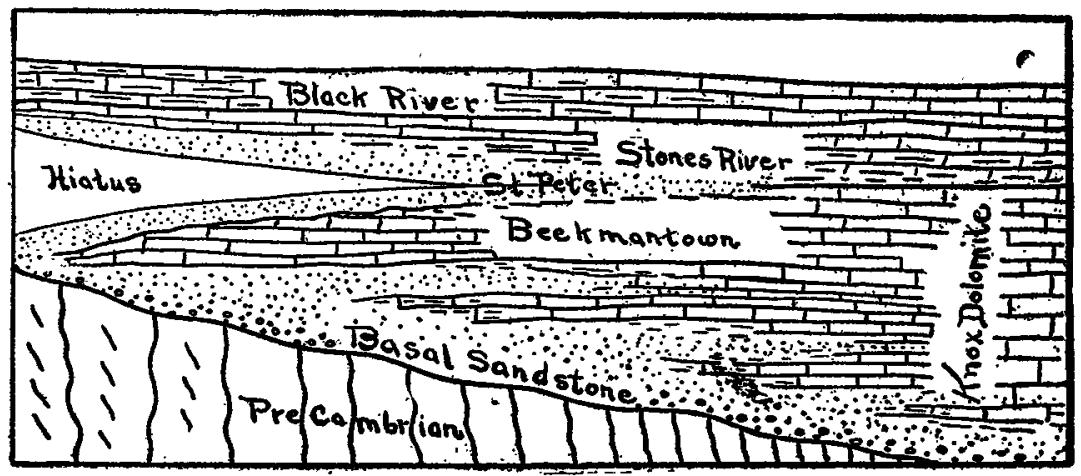

FIGURE 4.-Stratigraphic Range of the basal Sandstone.

This generalized sketch indicates the relationships of the Saint Peter formation to the larger groups representing deep-sea deposits, and lllustrating the conception of an erosion interval in Saint Peter time.

This relationship is well shown and fully discussed in the Geological Survey reports of Wisconsin.

When the evidence of unconformity is lacking there may nevertheless have been dry land at so nearly baselevel position that erosional forces were largely spent upon the loose mantle of shifting sands left by the outwash of the retreated sea. Here and there conditions were such as to permit penetration of this mantle and imprint the marks of an erosion interval on the undulating Shakopee. It is the writer's opinion that the Saint Peter sandstone is of such composition as to permit obliteration within itself of all marks of such an interval. This is probably true of all coarse grained or very pure sandstone formations. Great interbedded sandstones as a type doubtless represent periods of marked oscillations of

* Missourl Geological Survey, vol. vi, p. 357. 
level, with retreat of the sea, an erosion interval, a readvance of the sea. each with its characteristic deposits. Just as in displacements by folding or faulting, such disturbances are dissipated by ready adjustments among the easily shifted grains, so that occasionally all traces of the movements are wholly obliterated, so in like manner may an erosion interval be swallowed up and almost wholly lost in the shifting and worked orer sands that finally constitute the formation. It may easily happen that sands spread out by a retreating sea should be wholly worked over by the readvance, and yet, on a very uniform surface, leave no trace except a rather abrupt transition. In such a case the underlying bed would carry most of the marks preserved at all and might exhibit prominent erosional unconformity in limited areas. The overlying bed, in this instance the Stones River limestone, should be perfectly conformable, as descriptions show it to be (see figure 4 ).

Breccias are developed to a limited extent at some of the Saint PeterShakopee contacts, according to the records of both the Wisconsin and the Michigan reports. The Magnesian is represented as wedging out in an enveloping upper and lower sandstone wherever an original margin is preserved.

In Michigan this edge is the remnant of a bed partly destroyed by the encroaching Saint Peter sea, as at one time interpreted by Rominger, and beyond its present margin the Saint Peter should be expected to merge into the Great Basal sandstone ("Eastern sandstone") of the region. This interpretation, and indeed the presence of Saint Peter in Michigan at all, seems to have been regarded with doubt by many writers; yet there is no inconsistency about the occurrence in any respect, and the later state reports* under Doctor Lane add to the Saint Peter data. It is probable that the same type of edge was developed along the whole length of the ancient shoreline. In the extensive denudation of the region, however, this, together with all later deposits, has been destroyed except in the most protected localities.

In short, it is held that in the case of the Saint Peter evidence gathered from a study of its extent as well as its contacts and transitions is in support of a considerable erosion interval.

\section{Source of Supply of Materjat}

The Saint Peter sunds are widely and rather evenly spread. Considering the possible sources of supply, they are carried to surprising distances. There is no doubt at all of the sedimentary character of the

* Geological Survey of Michigan, Annual Reports for 1901 and 1903. 
rock; but for such a deposit all the sources in this case are marginal, except perhaps locally in Missouri; and of all the margins only the northern one seems to fulfill the conditions of a coastal supply. Along this northern coast there was at all times a broad and thick accumulation of sands from the waste of the continent. It lapped against the retreating shore in such position and in such condition that any considerable diastrophic movement elevating the land wonld subject great quantities of this loose material to the outwash of the sea and other transporting agencies. Any differential movement along this region might also subject underlying strata to erosion along the margin to the extent of destroying them, as is represented by Rominger in northern Michigan. Likewise any orographic movement or displacement by faulting, resuiting in the elevation of any considerable portion of the subcoastai margin, would still further augment the supply of these sands for seaward transportation.

In this connection it is recalled that there is extensive displacement by faulting within the area of the basal sandstones-Eastern and Western sandstones-of the Lake Superior margin. These movements were at least subsequent to the deposition of the chief mass of these formations, since the beds still remaining are much affected along this fault zone.*

It is not clear what time this faulting took place, but certain field relationships suggest that the displacement may have begun before the Lake Superior sandstones, as we now have them, were completed. At any rate, the raised blocks must have been capable of furnishing considerable excess of sand over regular erosion sources and must have resulted in some extension of the sand sediments seaward. The Saint Peter is the last of these sand extensions and certainly owes its existence to one or another of these dynamic factors, perhaps to all of them.

In the areas of no faulting in eastern Wisconsin the "Potsdam" thins out northeastward, according to the Wisconsin geologists, not by general thinning of all the beds, but by suppression of the lower members. It is worth while to note that this would not be true under normal conditions, except so far as overlap prevailed, and in case of retreat and advance with destruction of underlying beds.

To this phase of the problem the present condition of the underlying Shakopee dolomite adds evidence. The Saint Peter lies on the billowy surface of the Magnesian limestone, filling up its troughs and in most cases surmounting its prominences. In given instances 54 and 82 and 100 feet of sandstone was observed in these troughs, while adjacent knolls of magnesian dolomite had scarcely more than a film of sand to mark

* U. S. Grant: Bulletin vi, Geol. Survey, Wisconsin, p. 17. 
the separation* of this formation from the overlying Trenton (Stones River). This irregularity is greatest from Dodge county northward. In Missouri an inequality of this type is credited to actual stream erosion.

Few localities exhibit the Shakopee-Saint Peter contact well enough to furnish reliable data for most of the field. Hall and Sardeson have described this contact in Minnesota, also as uneven as a rule, but have considered it chiefly due to folding, $\dagger$ which dies out upward in the Saint Peter. The overlying Trenton (Stones River) is not affected. It seems well supported then, by combining the observations of all these men in their particular fields, that Saint Peter time was one of some considerable dynamic disturbance, that it resulted in both folding and faulting of the preceding series locally, and, in the region as a whole, was accompanied by diastrophic movements by which much of the Upper Mississippi valley and Great Lake regions became dry land for a part of the time.

Some characters of the formation (noted briefly under the heading of "Variability of the Saint Peter") bear on this problem and suggest further modification of the general interpretation.

\section{Structural Character and 'I'eXture}

A study of the texture of the Saint Peter made on specimens $\$$ gathered from localities of wide areal range furnishes a few suggestive facts.

Microscopic examination shows that in typical Saint Peter there is a total absence of large grains that are usually classed as gravel, and almost as complete absence of extremely fine grains, such as fall within the class of dust. In this respect there is no very marked difference among the various samples. The sands from La Salle, Illinois, and one sample from Wisconsin show most impurity.

The range of sizes runs from 1 millimeter down to .01 millimeter in a few cases, but the bulk of the rock is made up of grains from .4 millimeter to .05 millimeter in diameter.

The diameter of grains in samples examined from typical localities range prevailingly from .05 millimeter to .6 millimeter, an average for by far the greatest number of grains being from .1 to .2 millimeter. So far as different parts of the area or different horizons in the formation have been subjected to scrutiny, there is not any great variation. Hall and Sardeson, however, note that there is considerable diversity of texture

* Geology of Wisconsin, vol. 11, 1877, pp. 285-286.

† Bull. Geol. Soc. Am., vol. 3, p. 353 .

f For most of this material I am indebted to Dr W. M. Buckley, of Missouri; Superintendent Thomas J, McCormick, of La Salle, Illinols; Professor Ira A. Willams, of Ames, Iowa, and Professor C. K. Leith, of Wisconsin. 
in Minnesota, Olmstead, and Fillmore counties, in the southern part of the state, exhibiting much coarser grain than the Minneapolis-Saint Panl area. They also remark a noticeably coarser development at the base* of the formation at Cannon Falls and Northfield.

Under the microscope, grains from the Saint Paul area vary from .05 to 2 millimeters in diameter. Of these the larger grains are all much worn and as a rule very perfectly rounded, while the smalles, .1 millimeter and less, are strikingly more angular. This same relationship is shown by the samples from Missouri, where, however, the grains range as high as .6 millimeter in diameter and a greater proportion of them are woll rounded. The Fllinois rock is described as composed $\dagger$ of very uniform small round grains, as seen under the mieroscope. Specimens examined from Ia Salle county show more than the average impurity of iron and clay and fine matter.

Southern Irisconsin has a similar record. In Michigan the narrow strip through the upper peninsula that has been correlated with this formation $\ddagger$ is made up of the grains that are described as angular and associated in places with fragments of the preceding and destroyed edge of the magnesian.

Two samples from Iowa sent by Ira A. Williams, of Iowa State College, show the greatest range of any received. Both are from the eastern border of the state. In one the grains are nearly all large, some exceeding 1 millimeter, and all are rounded and beautifully pitted. The other is very fine grained, chiefly .05 to .1 millimeter in diameter, and also well worn. Both are very pure.

Only the larger grains in most of the samples are well rounded. Those of. .1 millimeter and over are all much worn. Commonly the smailcr grains, .0 millimeter and less in diameter, are strikingly more angular. In only one case, an lowa sample of very fine grain, are all grains worn. In one sample from Missouri, although the grains show marked secondary enlargement, the original character does not depart from the average type.

The worn grains in all the samples are heautifully pitted in the manner so often seen on wind-worn fragments. The agrecinent of the textural character of this rock with the requirements of a wind transported deposit is at once apparent. Every grain yet observed by the writer from this formation falls within the range of wind competence. According to the researches of J. A. Udden, grains comparable to those of largest

* Bull. Geol. Soc. Am., vol. 3, p. 351 .

$\dagger$ Geological Survey of Illinols, vol. v, p. 116.

$\ddagger$ Geology of Michigan, vol. I, pt. iii, pp. 56, 64, 72.

XX-Bull. Geol. Soc. AM., YoL. 17, 1905 
size in the Saint Peter, those most rounded, as noted above, would not be picked up and carried far by the wind, but could easily be rolled along the ground. The smaller sizes abundant in the rock fall within the lifting capacity of the wind and might be carried long distances.* These smaller sizes are prevailingly less worn and more angular than the larger sizes, and this again is consistent with such agency. Of all agents of transportation, wind is the best assorter. From a given supply of sand of reasonable areal limits the wind is able to remove the finer dust very perfectly. The finest and the coarsest particles are widely separated. If, therefore, the supply area is not so large as to outreach the assorting competence of prevailing winds, and if the winds involved are not so changeable as to undo one day what may have been accomplished on the previous one, the result is sure to be a perfectly cleaned sand.

\section{Conclustons as to ORIGIN}

The writer is well aware of the incompleteness of an argument of this kind. To find that certain phenomena are consistent with a certain explanation is far from proving its correctness; but, in view of the difficulty acknowledged by workers in the Saint Peter, it is at least worth noting that wind agency will account for the purity and textural character of this formation under very reasonable conditions.

The surface over which the Saint Peter sands were deposited was apparently very uniform. If it had departed far from a low-lying plain, we should doubtless have many marks of it in erosion forms characteristic of such elevation. On that plain, on its retreat, the sea spread great quantities of sand and left the marginal supply (Basal sandstone margin) exposed to all the transporting agencies. This the wind began to carry as dune sands along the shore. Into these sands the rivers sank as they coursed toward the retreating sea, accomplishing little in erosion. At the maximum retreat of the sea, it is the writer's belief that the Saint Peter sands presented the aspect of a shifting-sand plain, perhaps akin to a desert in this one feature at least, though not necessarily arid; so the sands were washed out by the retreat of the sea and thereby assorted, then worked many times over by the wind in the absence of the sea, and thereby still more perfectly assorted, and finally, in the readvance of the sea, much of it was again worked over a last time, thereby reaching its present remarkable condition of purity.

The Saint Peter therefore owes its constancy of grain and its purity

* J. A. Udden: The mechanical composition of wind deposits, Augustana Library Publications, No. 1, 1898. 
of composition, in the writer's opinion, not to chemical precipitation of the rock, not to subsequent leaching, but rather to the unusual completeness of the assorting process accomplished by wind and water on a sand largely derived from a previous sandstone formation. The marks of water action and sedimentation are too numerous to admit the chemical theory for an instant. As for subsequent removal by leaching, the results are too capricious for so general a cause. It has not removed the color stains that so commonly emphasize the structural features. It is impossible that nearly all the mineral dust, even that of the quartz type, should be removed by such agency and yet not attack the larger grains, even enough to destroy their wind-worn finish or the stains they carry. Such carbonate matter as accumulated in the sands has been remored largely, it is true, but there is no evidence of any considerable quantity of it ever having been present. For the removal of siliceous matter there is no evidence.

That the Saint Peter sandstone was deposited in water and preserves chiefly such structures as are common to sediments is certain; that its grains fall within the range of wind transportation and show characteristic wind-worn surfaces is equally clear; that the formation relationships argue an extensive retreat of the sea and an erosion interval is well supported-these factors alone are sufficient to account for all the peculiarities and remarkable characters of the Saint Peter, without any special agency.

\section{Physrographic Changes}

A reasonable interpretation of the foregoing facts and observations suggests the following outline of the physiographic changes of the time:

1. Just preceding the Saint Peter epoch the sea stood far in on the continental areas represented by Lanrentia at the north and Appalachia at the east. These were connected by an isthmus occupying the position of the Frontenac axis. To the eastward lay the Atlantic ocean and the gulf of Maine, in which the typical Beekmantown sediments were already accumulating. To the westward, in the great Mississippian sea, dolomites and limestones of the Magnesian series and their equivalents were being deposited.

2. With a reversal of epeirogenic movement the sea began to retreat. There were some marginal disturbances, perhaps both folding and faulting, by which arose subsequently some structural unconformity and through which possibly extra supplies of sands were made available.

3. At maximum retreat, judged by the distances to which heavy sands were carried, the whole upper Mississippi valley became dry land; it 
became a waste of drifting sands; but a deep bay extended northward to the southern boundary of New York, as appears from records of undisturbed sedimentation in Center county, Pennsylvania.

4. A readvance of the sea northward to the vicinity of its original position followed. In this movement the sands that had heen dragged out by the retreating sea and carried out by streams or transported in large part by winds were worked over, given their characteristic structures, and such fossils as belong to the formation were buried in them. The natural break representing the time interval, that would have been preserved in almost any other type of rock. is largely obliterated. With

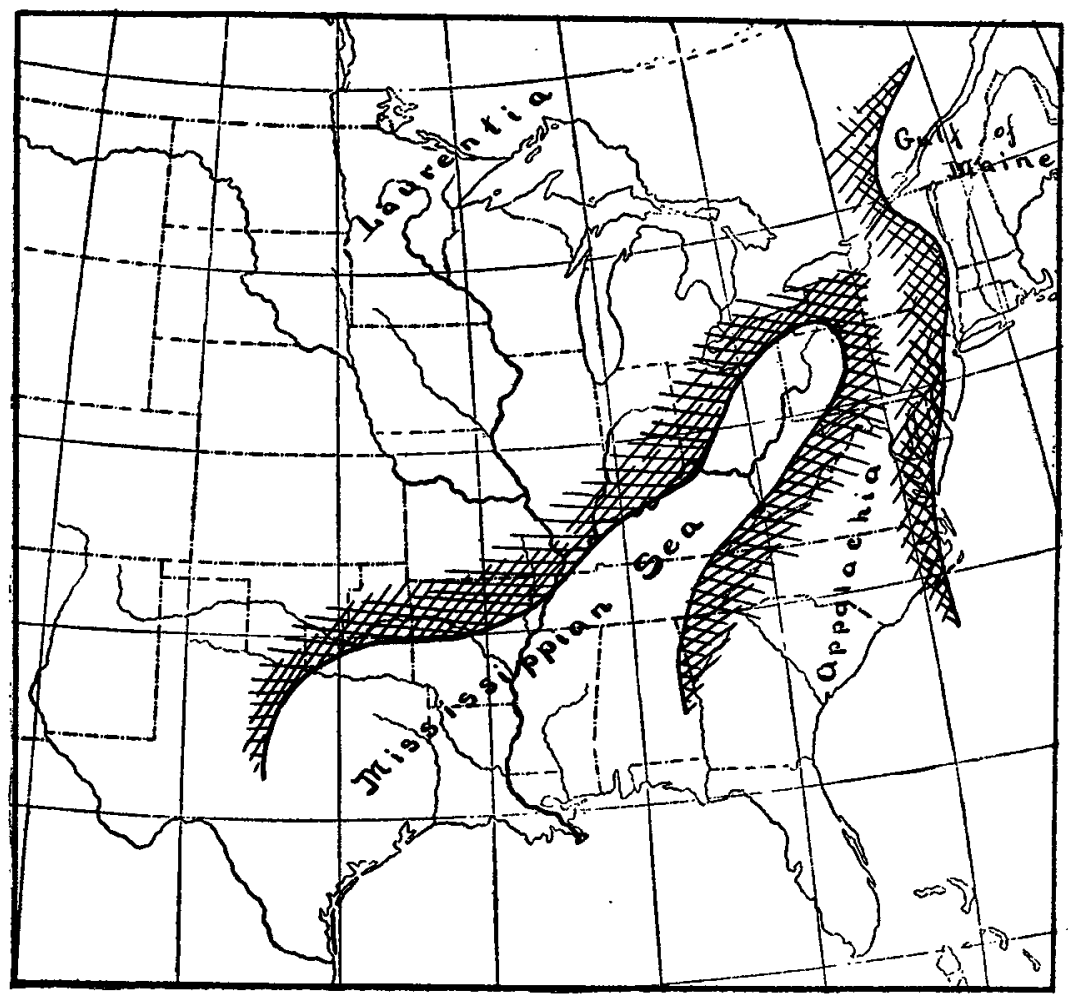

Figcre J.-Continental outlise at maximum Retreat of the Seus in millsaint

the oscillation, except locally along the margin, there is no evidence of unconformity of angle on a large scale. It appears also that in most localities the sea must have worked over almost the whole sand mantle. while in others the difference above and below the ehief zone of disturlance may be the foundation for the occasional suggestion that has been made to divide the formation into an upper and a lower Saint Peter. 
At the close of the whole revolution the continental land outlines differed very little from those immediately preceding the Saint Peter epoch.

\section{Paleogegraphic Charts}

Following out the conclusions involved in the foregoing discussion, the accompanying physiographic charts are presented (see figures jo and 6 ). They are an attempt to inclicate the land and sca distribution for the Mississippi valley in Saint Peter time. The lines drawn are general-

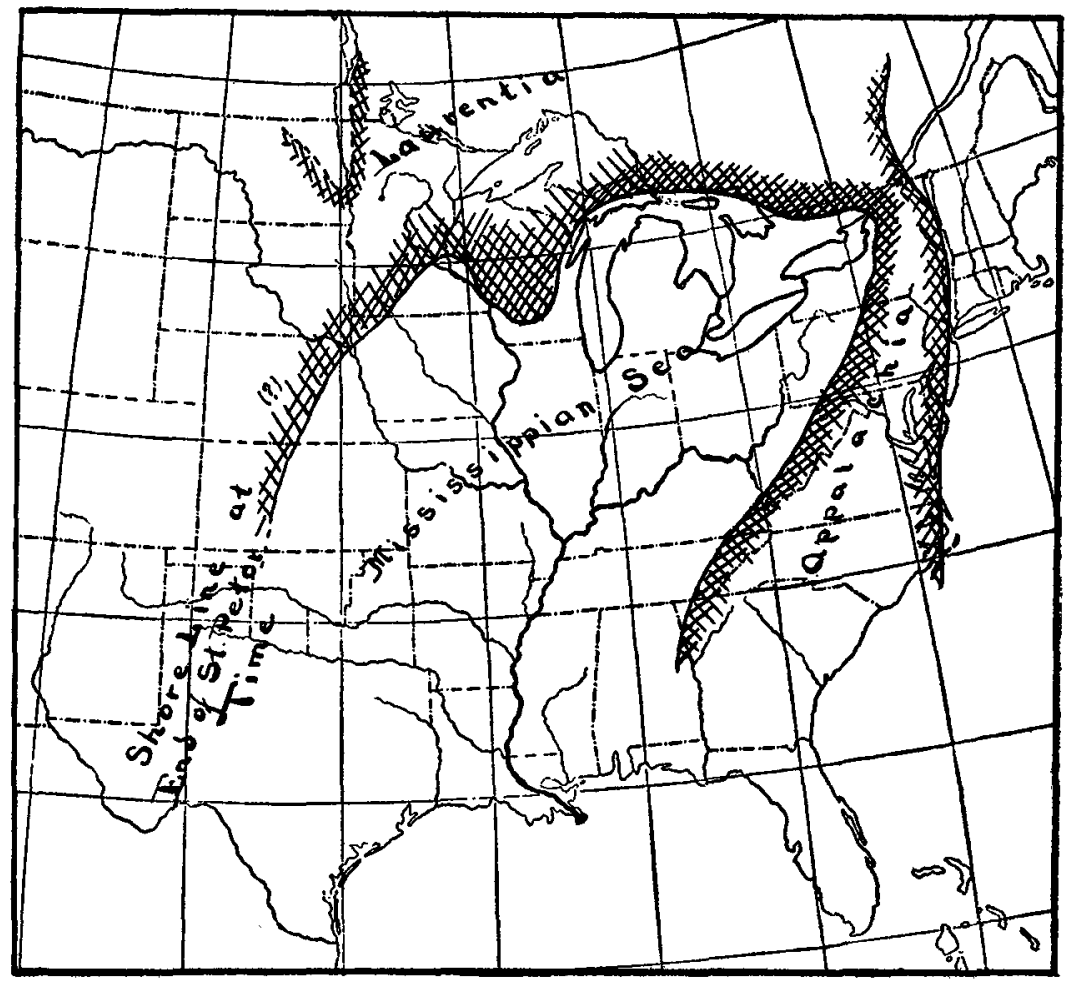

Figles 6.-Continental Outline new close of saint P'eler time.

izations and do not aim at local precision. It is intended to be understood that a maximum land area existed in mid-Saint Peter time, followed by a rapid encroachment of the sea to a coastline very like its pre-Saint Peter position.

The maximum retreat is drawn arbitrarily as interpreting the change of eharacter of sediments from offshore to deep-sea types. In the absence of data northward beyond the present limits of the formations involved, 
maximum advance margins are held near the existing known outcrops on the thin edges of equivalent beds.

\section{SUMMaRY}

Such facts as are known about the Saint Peter sandstone have been considered by the writer in support of the following general statements:

The Saint Peter sandstone is a mechanical sediment.

The sands were derived in large part from the upturned edges of preceding beds of sandstone and quartzites bordering the continental areas, and from the Basal Sandstone formation in particular, under conditions that made this an easy and abundant supply. 'The use of an already assorted material is one step in the production of its unusual characters.

The purity of the formation, the rounded and uniform size of grain, and its wide distribution over such a flat area indicate some agency of extraordinary sorting efficiency and transporting capacity. This is credited to the winds. The folded and faulted character locally of the underlying Shakopee with no effect on the overlying Stones River beds point to dynamic disturbances that occupied the Saint Peter epoch and ceased at its close. Hrosional unconformity between the Saint Peter and the Shakopee indicates that the same time was marked by a retreat of the sea. The widespread formation with uniform characters suggests a withdrawal of the sea from a very large area in the upper Mississippi valley.

As a conseruence, there was continuous deposition in the south and interrupted sedimentation in the north. The Saint Peter sandstone is stratigraphically a wedge including within itself a wedge-like break. In age the thin southern edge is younger than the lower beds and older than the highest beds, as they appear in the northern areas. 'The Saint Peter therefore should be found to overlap the Magnesian series seaward, but in turn should be itself overlapped by the limestones and shales of the Stones River group in its succeeding development landward. In certain localities it may be possible to divide the formation into an upper and a lower Saint Peter. 